\title{
The Effect of School-Based Program of Iron Supplementation in Preventing and Controlling Iron Deficiency Anemia Among Adolescent Girls: Literature Reviews
}

\author{
N. M. Parwati ${ }^{1,3, *}$, Pande Januraga ${ }^{2}$, Suarjaya $^{3}$ \\ ${ }^{1}$ Doctoral Study Program, Medical Faculty, Udayana University, Indonesia \\ ${ }^{2}$ School of Public Health Faculty of Medicine, Udayana University, Indonesia \\ ${ }^{3}$ Bali Health Office, Indonesia \\ *Corresponding author. Email: parwati.md@gmail.com
}

\begin{abstract}
The iron nutrition supplementation is an intervening strategy in tackling the anaemia deficiency among children and adolescent girls for the realization of a healthy and productive generation. To measure the effect of iron supplementation programs in increasing the concentration of haemoglobin and serum ferritin for the prevention and control of iron deficiency. The literature review was conducted using the sources from PubMed, Ebsco Health and Google Scholar database. Searches were limited to journals published between 2010 and 2019. There were 11 articles related to the effects of iron supplementation programs and iron fortification in schools. The articles discussed the intervention study that assessed the effects of iron supplementation in increasing the level of haemoglobin and serum ferritin. We found that there were variations in hematologic responses. Additionally, there was a significant increase in the level of haemoglobin and serum ferritin after the intervention of the program. The main predictor of the increase of the level of haemoglobin was the initial status of $\mathrm{Hb}$. We also found, however, that there were insignificant results in the samples with high initial haemoglobin level as well the intervention with the lack of supervision. Moreover, we found that during the period of 12-to-24-week intervention with frequency of the iron supplementation once a week, the concentration of haemoglobin decreased from $121.5 \mathrm{~g} / \mathrm{l}$, and on the $36^{\text {th }}$ week, there was a decrease of haemoglobin level to $119.1 \mathrm{~g} / \mathrm{l}$. The occurrence of the side effect of iron varies based on the frequency of the intervention. The implementation of a school-based program of iron supplementation is effective to increase the levels of $\mathrm{Hb}$ and ferritin in blood. The management of the program needs to involve the family members in terms of monitoring the constancy and the side effects. The sustainability of the program needs to be strengthened through education and motivation to teachers and students as well as the development of a comprehensive integrated system for the prevention and control of anaemia deficiency.
\end{abstract}

Keywords: effects, iron supplementation, adolescent girls, school based

\section{INTRODUCTION}

Iron deficiency anaemia is the most common malnutrition in the world caused by various factors such as inadequate nutritional intake, iron absorption or utilization, increased iron need during the infancy or blood loss due to parasitic infections [1].

It is estimated that throughout the world, in 2011 there were 600 million preschoolers and school-age children with anaemia, and it is assumed that at least half of these cases were caused by iron deficiency. Adolescent girls experience an iron loss of 12.5-15 mg per month or 0.4-0.5 $\mathrm{mg}$ of iron per day during menstruation. (WHO, CDC, 2018) [2].

Various studies have shown that foetal safety and health problems, low birth weight and dwarfism are related to adolescent girls' health and nutritional status.

The WHO recommendation as one of the main intervention strategies implemented by school to improve micronutrient in preschool and school-age children is iron and folic acid supplementation in women of reproductive age by giving iron once, twice or three times per week to prevent anaemia and improve their folate status [3]. 
This study was conducted to compare and evaluate the effectiveness and strategies of school-based programme of iron and folate tablets supplementation which is also aimed to be a recommendation to establish strategic efforts in optimizing the prevention of iron deficiency anaemia in adolescent girls.

\section{METHOD}

\section{Search Strategy}

The review was conducted using the literature form PubMed, Ebsco Health and Google Scholar. Searches were confined to articles analyzed by peer reviewers between 2010 and 2019.

\section{Inclusion Criteria}

The samples or study participants were young female students in elementary and secondary schools. The iron supplementation and/or iron fortification programme is aimed at the prevention and control of anaemia in adolescents girls at school. Additionally, we excluded articles that contain interventions outside of school.

\section{Selection Process}

Once we have idintified the titles and abstracts, we then screened them according to the inclusion criteria. The next stage is a full-text search to assess the feasibility of the articles and to delve into the detailed contents.

\section{Design and Synthetic Data}

The extraction of the articles in the literature review is shown in Table 1.

Table 1. Summary of Studies related to The Effect of School-Based Program of Iron Supplementation in Preventing and Controlling Anaemia Deficiency among Children and Adolescent Girls

\begin{tabular}{|c|c|c|c|c|}
\hline $\begin{array}{l}\text { Study, Year } \\
\text { of } \\
\text { publication, } \\
\text { Location }\end{array}$ & Study design & Sample & Intervention & Effect \\
\hline $\begin{array}{l}\text { Sesmaisons, } \\
\text { et al } \\
\text { Tahun } 2012 \\
\text { Vietnam }\end{array}$ & RCT & $\begin{array}{l}403 \text { children } \\
\text { (aged 6-9 } \\
\text { years) }\end{array}$ & 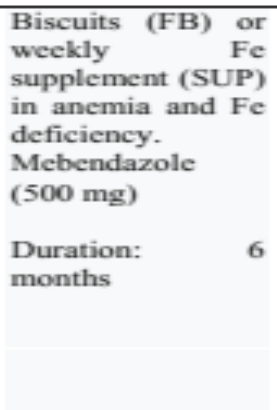 & $\begin{array}{l}\text { Indicated by a higher PF } \\
\text { (FB: geometric mean } 36 \\
-9(95 \% \text { CI } 28-0,55- \\
4) \text { mg } / 1 \text {; SUP: } \\
\text { geometric mean } 46-0 \\
(95 \% \text { CI } 33-0,71-7) \\
\text { mg } / 1 \text {; C: geometric } \\
\text { mean } 34-4(95 \% \text { CI } 15- \\
2,51-2) \text { mg } / 1 \text {; P, } 0- \\
\text { O01) and lower TFR } \\
\text { concentrations }(95 \% \text { CI } \\
4-8,6-52) \text { mg } / 1 ; \text { SUP: } \\
(95 \% \text { CI } 4-9,6-2) \\
(95 \% \text { CI } 5-1,7-1)\end{array}$ \\
\hline $\begin{array}{l}\text { Faruk } \\
\text { Ahmed et al } \\
2012 \\
\text { Bangladesh }\end{array}$ & $\begin{array}{l}\text { A } \\
\text { randomise } \\
\text { d, double- } \\
\text { blind, } \\
\text { controlled } \\
\text { trial }\end{array}$ & $\begin{array}{l}562 \text { non- } \\
\text { pregnant girls } \\
\text { (aged } 11-17 \\
\text { years) }\end{array}$ & $\begin{array}{l}\text { Supplementation } \\
\text { with once- and } \\
\text { twice-weekly } \\
\text { multiple } \\
\text { micronutrients } \\
\text { (MMN-1 and } \\
\text { MMN-2 }\end{array}$ & $\begin{array}{l}\text { Girls in the IFA-2 group } \\
\text { were more likely to be } \\
\text { anemic compared to girls } \\
\text { in the MMN-2 group at } \\
\text { week } 26 \text { (OR, } 5-1,95 \% \\
\text { CI } 1 \text { - } 3,19-5 ; \text { P } 1 \text { P4 } 0 \\
-018 \text {. The prevalence of } \\
\text { anemia in MMN-1 and } \\
\text { MMN-2, the group is } \\
\text { lower than in the IFA-2 } \\
\text { group. }\end{array}$ \\
\hline $\begin{array}{l}\text { Rucbeck } \\
\text { et al } \\
2016 \\
\text { Keonjhar } \\
\text { District, } \\
\text { Odisha }\end{array}$ & RCT & $\begin{array}{l}734: \text { in } 378 \\
\text { schools }\end{array}$ & $\begin{array}{l}\text { Iron tablets and } \\
\text { folic acid } \\
\text { iron tablets }(30 \\
\text { mg) } \\
\text { for } 100 \text { days }\end{array}$ & $\begin{array}{l}\text { IFASP tablets increase } \\
\text { children's hemoglobin } \\
\text { levels by } 0.280-0.307 \mathrm{~g} / \\
\text { dL. IFASP has an } \\
\text { insignificant effect on } \\
\text { students with high initial } \\
\text { hemoglobin levels. there } \\
\text { was a significant increase } \\
\text { in hemoglobin levels in } \\
\text { students with mild } \\
\text { anemia of } 0.49-0.84 \mathrm{~g} / \\
\text { dL }\end{array}$ \\
\hline $\begin{array}{l}\text { Gupta, } \\
\text { et al } \\
2014 \\
\text { India }\end{array}$ & RCT & $\begin{array}{l}331 \\
\text { adolescents } \\
\text { girls (aged 10- } \\
19 \text { years) }\end{array}$ & $\begin{array}{l}\text { Iron folate tablets } \\
\text { ( } 335 \mathrm{mg} \text { of iron } \\
\text { sulfate, } 100 \mathrm{mg} \text { of } \\
\text { elemental iron) } \\
\text { and } 500 \text { Hg of } \\
\text { folic acid given } \\
\text { daily and }\end{array}$ & $\begin{array}{l}\text { Hemoglobin increased in } \\
\text { all three groups. Once a } \\
\text { week, it increases to } 12.2 \\
\mathrm{~g} / \mathrm{dl} \text {, in the biweekly } \\
12.9 \mathrm{~g} / \mathrm{dl} \text {, and in the } \\
\text { daily group } 12.0 \mathrm{~g} / \mathrm{dl} \text {. } \\
\text { Serum ferritin also }\end{array}$ \\
\hline
\end{tabular}


Finkelstein,

J.L et al.

2015

India

Rousham,

EK

et al

2013

Pakistan

Duque. $\mathrm{X}$,

et al

Tahun 2014

Mexico City

Goyle

Tahun 2010

India
A

randomize d trial

Cluster-

randomize

d

controlled

trial

A

randomize

d, double-

blind

clinical

trial

Interventio

n study

(pre-post

interventio

n)

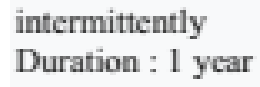

intermittently

Duration : 1 year

246 children (12-16 years old)

Children and

Adolescents, aged 5-17

years

200

Children

92 school

children

aged

10-16 years weeks. weeks.

\section{Supplementation}

increased in all three intervention groups. Once a week, it increases to $35.5 \mu \mathrm{g} / 1$.

At baseline, $41 \%$ of children were iron deficient ( $S F<15 \mathrm{mg} / \mathrm{L}$ ) and $28 \%$ had anemia (hemoglobin $<12.0 \mathrm{~g} /$ dL).

Fe-PM significantly increased the concentration of SF and TBI after 4 months compared to Control-PM (Pearl Millet).

Supplements once a week, the average hemoglobin

A single weekly dose of 24 weeks (200 $\mathrm{mg}$ of ferrous sulfate containing $63 \mathrm{mg}$ of elemental iron) and students in 10 schools were given the same iron supplement $2 \mathrm{x} /$ week for 12

Daily supplement $30 \mathrm{mg} /$ day of the element iron as ferrous sulfate or iron bis-glycinate chelate for 12 of biscuits enriched with 30 $\mathrm{mg}$ of iron, 100 $\mathrm{mg}$, folic acid, $600 \mathrm{mg}$ of vitamin A, $40 \mathrm{mg}$ of vitamin $\mathrm{C}$ and 150 $\mathrm{mg}$ of iodine.

Duration : 3 months concentration shows an insignificant increase between baseline and 12 weeks.

From 12 to 24 weeks, the average hemoglobin concentration drops to $121.5 \mathrm{~g} / 1$, and then to $119.1 \mathrm{~g} / 1$ at 36 weeks.

Hemoglobin

concentrations did not change significantly in the two groups after supplementation.,Parasiti $c$ infections can affect the improvement of iron status such as malaria endemic use of iron supplements to be extended

The threefold increase in teenage girls in the from 4.3 to 13.0 percent and a decrease in the 'moderate' anemia category from 67.4 to 28.3 percent 'normal' anemia category 


\begin{tabular}{|c|c|c|c|c|}
\hline $\begin{array}{l}\text { Rezacian, A } \\
\text { et al } \\
2014 \\
\text { Iran }\end{array}$ & $\begin{array}{l}\text { A blind } \\
\text { controlled } \\
\text { clinical } \\
\text { study trial. }\end{array}$ & $\begin{array}{l}200 \text { female } \\
\text { students } \\
\text { secondlary } \\
\text { school. }\end{array}$ & $\begin{array}{llr}50 \mathrm{mg} \text { of } & \text { iron } \\
\text { sulfate } & \text { twice } & \text { a } \\
\text { week } & \text { for } & 16 \\
\text { weeks. } & & \end{array}$ & $\begin{array}{l}\text { control groups were } \\
104.8 \pm 7.0 \text { and } 52.7 \pm \\
9.6, \text { respectively (p } \\
<0.001) \text {. The mean } \\
\text { hemoglobin levels of the } \\
\text { two groups were } 12.5 \pm \\
0.9 \text { and } 11.2 \pm 1.0 \text {, } \\
\text { respectively }(p<0.001) \text {. }\end{array}$ \\
\hline $\begin{array}{l}\text { Jawarkar, } \\
\text { A.K et al } \\
2015 \\
\text { India }\end{array}$ & $\begin{array}{l}\text { Quasi } \\
\text { ex- } \\
\text { periment } \\
\text { pre-post } \\
\text { interventio } \\
\text { n }\end{array}$ & $\begin{array}{l}350 \\
\text { Adolescent G } \\
\text { irls }\end{array}$ & $\begin{array}{l}\text { Single-dose } \\
\text { anthelminthic and } \\
\text { iron tablets and } \\
\text { folic acid for daily } \\
\text { consumption } \\
\text { Duration: } 3 \\
\text { months }\end{array}$ & $\begin{array}{l}\text { The mean and standard } \\
\text { deviation of } \mathrm{Hb} \% \text { in } \\
\text { adolescent girls } \\
\text { increased significantly } \\
\text { from } 10.57 \text { ( } \pm 1.09) \\
\text { before to } 11.78( \pm 0.99) \\
\text { after the intervention. } \\
\text { The average Hb } \\
\text { increased by } 1.21 \text { grams } \\
\text { after iron } \\
\text { supplementation. }\end{array}$ \\
\hline $\begin{array}{l}\text { Tyas } \\
\text { Permatasari' } \\
\text { et al } \\
2018 \\
\text { Indonesia }\end{array}$ & $\begin{array}{l}\text { Quasi } \\
\text { experiment } \\
\text { t pre-post } \\
\text { interventio } \\
\text { n }\end{array}$ & $\begin{array}{l}172 \\
\text { Adolescent } \\
\text { girls }\end{array}$ & $\begin{array}{l}\text { Tablets ( } 60 \mathrm{mg} \text { of } \\
\text { elemental iron } \\
\text { and } 0.25 \mathrm{mg} \text { of } \\
\text { folic acid) } \\
\text { supplementation } \\
\text { with weekly } \\
\text { periods and } 10 \\
\text { tablets during } \\
\text { menstruation } \\
\text { Duration: } \\
\text { months }\end{array}$ & $\begin{array}{l}\text { The prevalence of } \\
\text { anemia }(\mathrm{Hb}<12 \mathrm{~g} / \mathrm{dl}) \\
\text { before the program was } \\
20.7 \% \text { and decreased to } \\
15.2 \% \text { initial Hb status (p } \\
<0.05 ; \text { OR }=3.52 \text {; } \\
\text { C195\% = 1.40-8.8 }\end{array}$ \\
\hline
\end{tabular}

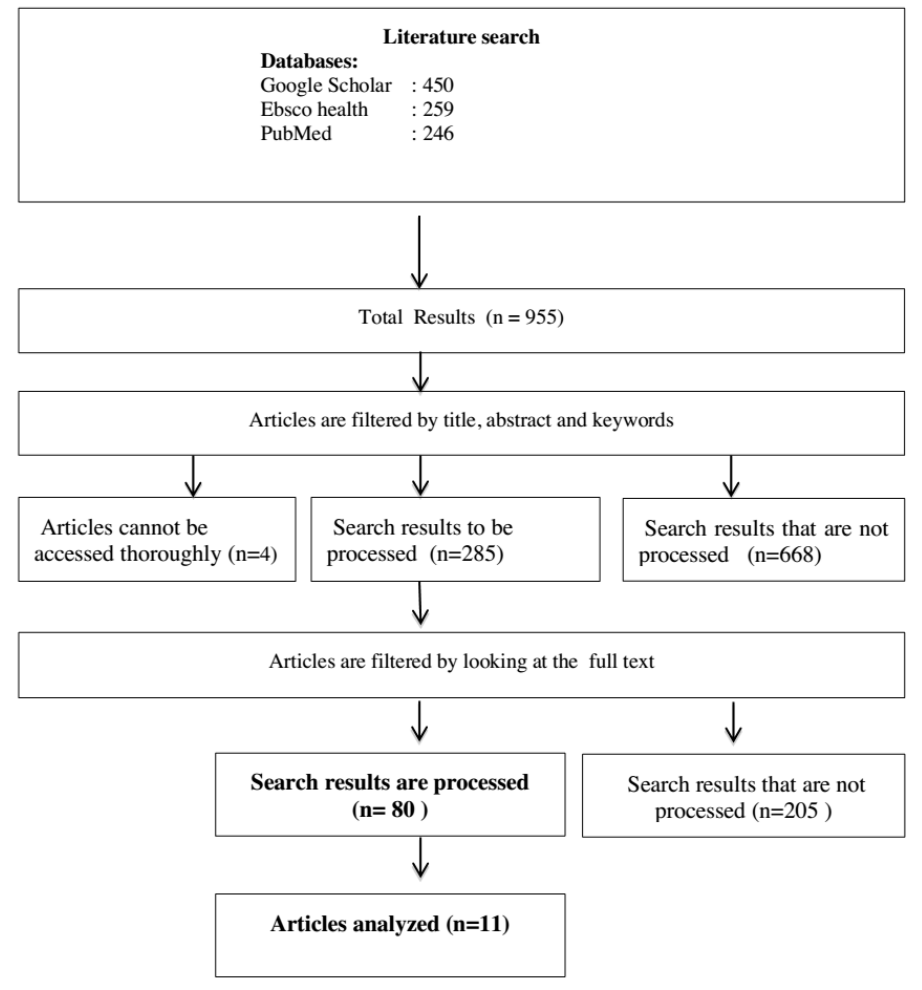

Figure 1. Flow chart of the literature search process 
increase children's haemoglobin level as much as 0.280 -

\section{School-Based Programme of Iron Supplementation for Children and Adolescent Girls}

Since children's activities are mostly done in school, this place is considered to be an appropriate and effective location to monitor the compliance and evaluate the reactions after taking iron tablets. Iron supplementation was given every day until the haemoglobin concentration rises to normal level. It is then switched to the intermittent regimen to prevent the recurrence of anaemia. These intermittent iron supplements can be integrated into school or community programmes.

The intermittent use of oral iron supplements has been proposed as an effective alternative for preventing anaemia in children and adolescent girls.

Oral supplements are available in drops and syrup for preschoolers and tablets or capsules for school-age children. (WHO, 2018) [2].

\section{RESULTS AND DISCUSSION}

\section{Effects of School-Based Iron Supplementation Programs}

We examined eleven articles using Randomized Controlled Trial design including quasi-experimental to measure the effects of the programme related to the hematological profiles and other factors related to the success of the programme. The sample was girls from different age groups. The intervention supplements were not limited to iron tablets but also iron fortification with varying duration.

The 11 articles showed the use of various types of interventions such as elemental iron tablet supplementation (Faruk Ahmed, 2012; Rousham, 2013; Rezaeian, 2014; Duque, 2014; Gupta, 2014); Jawarkar AK, 2015; Ruebeck, 2016; Permatasari, 2018) and biofortification (Goyle, 2010; Sesmaisons et al., 2012; Finkelstein, 2015)

All studies showed that a single dose of anthelminthic for the control of helminth infections and periods of iron tablets varies between daily, weekly and intermittent intervensions with the longest period of intervention is one year. Not all studies showed a significant increase in haemoglobin and ferritin levels. A significant increase in haemoglobin levels from $10.57( \pm 1.09)$ to $11.78( \pm 0.99)$ occured after the intervention. Haemoglobin increased by an average of 1.21 grams after iron supplementation [4]. Hemoglobin levels increased on from $12.5 \pm 0.9$ and 11.2 $\pm 1.0(\mathrm{p}<0.001)$ for both groups [5].

There is also an increase in haemoglobin after supplementation but it is insignificant.

No difference is found in blood ferritin concentration [6]. Faruk Ahmed also found that the long-term intervention of iron supplementation can effectively boost the micronutrient status without a significant increase in hemoglobin concentration ((OR, 5 - 1, 95\% CI 1 - 3, 19 . 5; P 1 P4 0 - 018.). Ruebeck reports that IFASP tablets can
$0.307 \mathrm{~g} / \mathrm{dL}$ [7].

IFASP has an insignificant effect on students with high initial haemoglobin level. These students also experienced insignificant negative effects from the interaction of anthelmintics and iron supplements. There was also a better increase where the average haemoglobin level was relatively higher in the biweekly group compared to the groups with weekly and daily intervention (ANOVA statistics $\mathrm{F}=6.08, \mathrm{P}=0.003$ ) [8].

The supplementation of biscuits enriched with several micronutrients shows effective results in reducing the prevalence of anaemia among school children. Interventions must consider other deficiencies besides $\mathrm{Fe}$ [9]. The initial impact shows that the effect of the intervention can vary according to the initial iron status. Also, the consumption of iron-biofortified pearl millets significantly improves iron status in children [10]. There is a threefold increase in haemoglobin level among teenage girls grouped in 'normal' anaemia category. It increased from 4.3 to 13.0 percent. There is also a twofold decline among those in 'moderate' anemia category from 67.4 to 28.3 percent with biscuit supplementation enriched with $30 \mathrm{mg}$ of iron, $100 \mathrm{mg}$ of folic acid, $600 \mathrm{mg}$ of vitamin A, $40 \mathrm{mg}$ of vitamin $\mathrm{C}$ and $150 \mathrm{mg}$ of iodine.

\section{DISCUSSION}

\section{Anemia}

One study with 350 participants showed that there is an increase in the harmoglobin level in adolescence with anaemia after the daily consumption of iron tablets. Three children with severe anaemia were hospitalized [4].

The biggest and the only statistically significant effect from the IFASP (India's Iron and Folic Acid Supplementation Program) for 100 days occurred in students with mild anaemia. IFASP causes a significant increase in haemoglobin level of 0.49-0.84 g / dL [8]. Average increase of haemoglobin levels is relatively higher in the biweekly groups compared the weekly and daily groups (ANOVA statistics $\mathrm{F}=6.08, \mathrm{P}=0.003$ ) [12]. The intervention of iron tablets in 172 girls during menstruation, before and after the weekly iron intervention program and 10 tablets during menstruation, showed insignificant results in the increase of haemoglobin level. Iron supplements with the frequency of 1-2 times per week is not associated with the significant increase of haemoglobin concentration. The initial haemoglobin concentration is the the strongest predictor of haemoglobin increase. The lack of improvement can come from the basic prevalence of moderate anaemia (33\%); other micronutrient deficiencies [13].

Another result showed that the hemoglobin concentration did not change significantly in both groups after 6 months of supplementation. IFASP has no significant effect on increasing haemoglobin level in students with high initial haemoglobin level. These students also experienced insignificant negative effects from the interaction between anthelmintics and iron supplements $[6,8,13,14]$. Children 
who received intermittent iron supplementation on a weekly basis have experience a good effect on increasing their haemoglobin and ferritin level with minor effect on digestion. ${ }^{5}$ Supplementation with fortified iron has shown mixed results on the increase of haemoglobin level [9][10][11]. Average fortification of iron supplementation has minimal side effects with positive effects on increasing haemoglobin levels. Increased ferritin level is not always followed by the increase of haemoglobin [9][11].

The duration of the program supports the effectiveness of preventive interventions of iron deficiency anaemia and to increase ferritin level. Supplements can also help schoolage populations maintaining adequate iron status. For the areas infected by parasites (e.g. malaria endemic) the duration of iron supplementation needs to be extended to increase the iron status [6].

\section{Intermittent Iron Supplementation Versus Daily Iron Supplementation.}

With the various nutritional composition of supplements (iron only; iron + folic acid; iron + other nutrients; iron + lots of micronutrients + fortified iron), either intermittent or daily doses has a variety of effects in increasing haemoglobin levels. It is reported that there is a minimal side effect when intervened by weekly supplementation such as nausea and vomiting, while the side effect if higher when interved by daily supplementation $(n=43,55 \%)$ compared to biweekly $(\mathrm{n}=20,25 \%)$ and weekly group (n $=14,18 \%)(\chi 2=28.2, \mathrm{P} \leq 0.001)$ [12]. Either daily or intermittent dosages does not directly influence the significance of elevated hemoglobin level.

\section{Adherence}

There are only two studies reporting the aspects of adherence in the consumption of iron supplementation.

There is a statistically significant difference in compliance with programme evaluation results. Lack of supervision and motivation can affect the increase of haemoglobin level p <0.05; OR = 3.52; CI95\% = 1.40-8.85 [7][14]].

Jawarkar et.al. stated that $18 \%$ of children did not regularly consume the iron tablets due to side effects such as metallic taste, nausea and abdominal pain after consumption [4]. Besides, side effects from iron supplementation, especially in high dosage, can result in the lack of patient compliance [5].

Anaemia and micronutrient assessments need to be done as a pre-intervention evaluation so that changes can be seen after the intervention. Also, each program should include supplementation compliance monitoring activities and the identification of possible obstacles in order to make anticipatory efforts as early as possible.

Research shows that side effects always occur when iron intake is given daily which is why intermittent supplementation should be considered and evaluation should be done to determine the regular iron consumption. Successful implementation of the program requires joint efforts. It needs the involvement of the family to help the prevention and control of anaemia.

\section{CONCLUSION}

The prevention and control of anaemia in adolescent girls are very important to support the achievement of healthy and quality children and adolescents girls. School-based programme of iron supplementation is effective in increasing the haemoglobin level and blood ferritin levels. To manage the progamme well, it needs family involvement in terms of supervision of compliance and side effects to achieve the regularity of consumption. To ensure the sustainability of the program, we need to strengthen the education and motivation among teachers and school children and develop an integrated and comprehensive system to control iron nutrition anaemia.

\section{ACKNOWLEDGMENT}

The authors thank all parties who have supported and assisted in writing this literature review.

\section{REFERENCES}

[1] WHO. (2011).Guideline: Intermittent Iron Supplementation In Preschool And School-Age Children. Geneva, World Health Organization. Available on the WHO web site (www.who.int) Accessed 13 Agust 2018).

[2] WHO. (2018). Weekly Iron And Folic Acid Supplementation As An Anaemia-Prevention Strategy In Women And Adolescent Girls: Lessons Learnt From Implementation Of Programmes Among Non-Pregnant Women Of Reproductive Age. Geneva: World Health Organization; available on the WHO web site (www.who.int) Accessed 16 Agust 2019.

[3] WHO. (2011). Weekly Iron And Folic Acid Supplementation Programmes For Women Of Reproductive Age: An Analysis Of Best Programme Practices. Manila, World Health Organization Regional Office For The Western Pacific, available: http://apps.who.int/ book orders, Accessed 19 Agust 2019.

[4] Jawarkar, A. K. et al. (2015) 'Prevalence Of Anaemia And Effectiveness Of Iron Supplementation In Anemic Adolescent School Girls At Amravati City(Maharashtra )' Journal Of Health Research And Reviews || Volume 2 | Issue, 2(1), pp. 7-10.

[5] Rezaeian, A. et al. (2014) 'Effects of iron supplementation twice a week on attention score and haematologic measures in female high school students', Singapore Med J 2014; 55(11): 587-592, 55(11), pp. 587592.

[6] Duque, X. et al. (2014) 'Effect of supplementation with ferrous sulfate or iron bis-glycinate chelate on ferritin concentration in Mexican schoolchildren : a randomized controlled trial', Nutrition Journal 2014, 13:71, pp. 1-10.

[7] Ahmed, F. et al. (2012) 'Effect of long-term intermittent supplementation with multiple micronutrients 
children in north-west Pakistan. Eur J Clin Nutr; 67(11):1188-92

[14] Permatasari, T., Briawan, D. and Madanijah, S. (2018) 'Efektivitas Program Suplementasi Zat Besi pada Remaja Putri di Kota Bogor Effectiveness of Iron Supplementation Programme in Adolescent girl at Bogor City', J. MKMI, Vol. 14 No. 1, 14(1), pp. 1-8. Maret 2018, 14(1), pp. 1.

[9] Sesmaisons, D. et al. (2012) 'Multi-MicronutrientFortified Biscuits Decreased The Prevalence Of Anaemia And Improved Iron Status, Whereas Weekly Iron Supplementation Only Improved Iron Status in Vietnamese School Children British Journal of Nutrition', pp. 1419-1427.

[10] Finkelstein, J. L. et al. (2015) 'A Randomized Trial of Iron-Biofortified Pearl',. J Nutr 2015;145:1576-8.

[11] Goyle, A. (2010) 'Effect of supplementation of micronutrient fortified biscuits on hemoglobin and serum iron levels of adolescent girls from Jaipur city, India', India', Nutrition \& Food Science Vol. 40 No. 5, 2010 Pp. 477-484, 40(5), Pp. 477-484. 40(5), pp. 477-484.

[12] Gupta, A. et al. (2014) 'Combating Iron deficiency anemia among school-going adolescent girls in a Hilly State of North India: Effectiveness of intermittent versus daily administration of iron-folic acid tablets', International Journal of Preventive Medicine, 5(11), pp. 1475-1479.

[13] Rousham EK, Uzaman B, Abbott D, Lee SF, Mithani $\mathrm{S}$, Roschnik N, et al. The effect of a school-based iron intervention on the hemoglobin concentration of school 